\title{
Prevention and control of viral diseases in watermelon through botanical biopesticides
}

\author{
Sharma NK, Shyam Singh and Awasthi LP* \\ N.D. University of Agriculture and Technology, Kumarganj, Faizabad-224229 (U.P.), India
}

\begin{abstract}
In the experiments, conducted for the prevention and control/eco-friendly management of the viral diseases of watermelon, through botanical biopesticides, seed treatment followed by 6 foliar sprays with $B$. diffusa root extract was found most effective against natural infection of viral disease(s) as compared to seed treatment followed by six foliar sprays with $A$. indica, seed treatment followed by six foliar sprays with $C$. aculeatum and seed treatment followed by six foliar sprays with $T$. arjuna. The appearance of disease symptoms was significantly delayed with six foliar sprays along with seed treatment with $B$. diffusa root extract followed by six foliar sprays along with seed treatment with $A$. indica, six foliar sprays of $B$. diffusa, six foliar sprays along with seed treatment with $C$. aculeatum, six foliar sprays of $A$. indica, six foliar sprays of $C$. aculeatum, six foliar sprays along with seed treatment with $T$. arjuna bark extract. A gradual decrease in disease incidence was recorded along with corresponding increase in number of sprays of the antiviral agents. Minimum disease incidence was recorded in plots, which have seed treatment followed by six foliar sprays of B. diffusa root extract and was significantly lower over rest of the treatments. As the number of sprays increased along with seed treatment, a gradual increase in vine length, number of fruits plant ${ }^{-1}$, fruit diameter, fruit weight and fruit yield were recorded in all botanical treatments. Most effective botanical found was $B$. diffusa root extract which exhibited maximum vine length, number of fruits plant ${ }^{-1}$, fruit diameter, fruit weight and fruit yield followed by $A$. indica leaf extract, C. aculeatum leaf extract and T. arjuna bark extract.
\end{abstract}

\section{Introduction}

Watermelon [Citrullas lanatus (Thumb) Mastum and Nakai, Synonyms: C. vulgaris] is one of the most popular desert fruit grown all over world. In India it is grown, mostly as riverbed side crop, in Uttar Pradesh, Rajasthan, Gujarat, Maharastra, Punjab and Haryana. This crop is infested by many biotic and abiotic factors and caused great economic losses. The low productivity of watermelon is mainly due to many diseases incited by viruses, fungi, bacteria, nematodes and phytoplasma. A large number of viruses have been reported from time to time to infect this crop viz., watermelon mosaic virus- 1 [1], watermelon mosaic virus-2 [2], zuchini yellow mosaic virus [3], cucumber mosaic virus [4-9], papaya ring spot virus [10], watermelon chlorotic stunt virus [11] melon necrotic spot virus [12], watermelon silver mottle virus [13], watermelon bud necrosis virus [16] and watermelon curly mottle virus [14], which induced mild to severe mosaic, yellowing, chlorosis, necrosis, puckering, distortion, mottling and stunting symptoms. Severely infected plants did not bear flowers and could not produce fruits. In a very few cases, if flowers appeared, very small sized distorted fruits were produced.

Plant viruses are persistent threat to production of watermelon in most of the countries including India. Although severe outbreaks of viral diseases tend to occur on a sporadic basis, many plant viruses are ubiquitous in nature and can result in severe outbreaks under favorable conditions. Management of viruses is usually limited to the availability of resistant varieties, besides vector control. However, commercially acceptable varieties that are also resistant to particular virus or several commonly occurring viruses often are not available. Therefore, the solution for the management of viral diseases of watermelon lies in the strategies of the integration of several methods, such as chemical, cultural, varietal, and botanical to control both viruses and their vectors. Synthetic agro chemicals commonly used to kill insect vectors, for the management of viral diseases, cause environmental pollution, health hazards and phytotoxicity besides their very high cast. Use of such agrochemicals can be avoided by some preventive measures/immunization through antiviral substance of plant origin, botanical biopesticides [15-19]. These substances are nonchemical, nonhazardous, easily biodegradable, did not leave any residual effect on soil, water and environment and are eco-friendly, besides their very low cast [20-24].

The objective of the present investigation was to find out ecofriendly management strategies for viruses infecting watermelon through botanical biopesticides in Indian context.

\section{Materials and methods}

The experiments were conducted at Horticulture Research Farm, N.D. University of Agriculture and Technology, Faizabad, India. Experiment layout was Randomized block design (RBD) with fourteen treatments and three replications. Experimental lay out was made as per treatments and replications. Forty-two plots were laid out for this experiment. The plot size was $6 \times 4.5 \mathrm{~m}\left(27 \mathrm{~m}^{2}\right)$ accommodating 9 plants in each plot. The main irrigation channel was provided in eastern side of the experimental field and the sub irrigation channels were prevailed between two replications of the treatment. Seeds of variety Sugar Baby were sown separately in $6 \mathrm{~m} \times 4.5 \mathrm{~m}$ plots with row to row distance of $2 \mathrm{~m}$ and plant to plant distance of 1.5 meter. Treatments details are given below:

Correspondence to: Awasthi LP, Amity Center for Research and Innovation (Amity University, Uttar Pradesh), Varanasi-221007(U.P.), India, Tel: 919415718904; E-mail: lpawasthi14@gmail.com

Key words: antiviral, foliar sprays, treatment, disease incidence, biopesticide

Received: May 24, 2017; Accepted: June 20, 2017; Published: June 22, 2017 


\section{Treatments details}

1. The experiments were conducted with 14 treatments and 3 replications as below.

$\mathrm{T}_{1}=$ Seed treatment with Boerhaavia diffusa root extract (BD) @ 10\%

$\mathrm{T}_{2}=$ Seed treatment with Clerodendrum aculeatum leaf extract (CA) @ 10\%

$\mathrm{T}_{3}=$ Seed treatment with Azadirachta indica leaf extract (AI)@ 10\%

$\mathrm{T}_{4}=$ Seed treatment with Terminalia arjuna bark extract (TA) @ 10\%

$\mathrm{T}_{5}=$ Foliar sprays of Boerhaavia diffusa root extract (BD) @ 10\%

$\mathrm{T}_{6}=$ Foliar sprays of Clerodendrum aculeatum leaf extract (CA) @ 10\%

$\mathrm{T}_{7}=$ Foliar sprays of Azadirachta indica leaf extract (AI) @ 10\%

$\mathrm{T}_{8}=$ Foliar sprays of Terminalia arjuna bark extract (TA) @ 10\%

$\mathrm{T}_{9}=\mathrm{T} 1+\mathrm{T} 5$

$\mathrm{T}_{10}=\mathrm{T} 2+\mathrm{T} 6$

$\mathrm{T}_{11}=\mathrm{T} 3+\mathrm{T} 7$

$\mathrm{T}_{12}=\mathrm{T} 4+\mathrm{T} 8$

$\mathrm{T}_{13}=$ Control (water alone)

$\mathrm{T}_{14}=$ foliar sprays of insecticides

2. Variety- Sugar baby

3. Design- Randomized block design (RBD)

4. Replications-Three

\section{Preparation of botanical bio pesticides}

Roots of Boerhaavia diffusa L., leaves of Clerodendrum aculeatum L. and Azadirachta indica L. and bark of Terminalia arjuna L. were collected separately and allowed to dry under shade at room temperature. Dried roots, leaves or bark were ground separately to powder and stored at low temperature. The crude extracts, in each case, were prepared by making the suspension of root, leaf or bark powder separately in the tap water $(1 \mathrm{~g} / 10 \mathrm{ml})$. The pulp was stained through two folds of cheese cloth and the homogenate was clarified by centrifugation at $8,000 \mathrm{~g}$ for 15 minutes. The supernatants obtained following the procedure as described earlier $[20,21,23,24]$, were used for experimental work $[16,17]$.

\section{Procedure of application/treatments}

i. Seed treatment: One hundred seeds of watermelon variety, sugar baby were soaked either in the root extract of $B$. diffusa, leaf extract of $C$. aculeatum or A. indica or the bark extract of T. arjuna, for 30 minutes to one hour. Seeds were then taken out from treatment solutions and spread over a gunny bag, under shade for about two hours. Sowing was done in the afternoon. Seeds soaked exactly in the same way in water for the same time served as control. The treated and untreated seeds were sown in $6 \times 4.5$ meter plots with row to row distance of $2 \mathrm{~m}$ and plant to plant distance of 1.5 meter.

ii. Field sprayings: The first spray of plant extract, in each case separately, was done 4-6 days after germination at cotyledons stage (2 leaf stage) followed by second, third, fourth, fifth and sixth sprayings at fortnightly intervals. In control plots, water alone was sprayed instead of plant extracts. Insecticide Endosulphan @ 1ml/L water was sprayed to eliminate insect vectors, if any.

\section{Observations recorded}

Observations were recorded on first appearance of disease, disease incidence, and plant height, number of fruits, fruit yield and yield losses.

First appearance of disease: Observations were recorded at regular intervals for the first appearance of disease symptoms in treated and un-treated plots separately.

Disease Symptoms: Symptoms were recorded at regular time interval in all the treatments on the basis of visual observations.

$$
\begin{aligned}
& \text { - = No symptoms } \\
& +=\text { Very mild symptoms } \\
& ++=\text { Mild symptoms } \\
& +++=\text { Moderate symptoms } \\
& ++++=\text { Severe symptoms } \\
& ++++++=\text { Very severe symptoms }
\end{aligned}
$$

Disease incidence: The number of plants infected, with naturally occurring watermelon viruses, out of total number of plants in a plot, was recorded. Per cent disease incidence and per cent disease control were calculated by the following formula:

$$
\begin{aligned}
& \text { Disease incidence }(\%)=\frac{\text { Number of infected plants per plots }}{\text { Number of plants (disease }+ \text { healthy) per plants }} \times 100 \\
& \text { Per cent disease control }(\mathrm{PDC})=\frac{\mathrm{C}-\mathrm{T}}{\mathrm{C}} \times 100
\end{aligned}
$$

Vine length: Length of vine in meter was recorded from the ground level to tip of the vine at the last picking (maturing stage).

Number of fruits per plant: The total number of fruits were counted at each picking separately and summed up for all pickings for a plot. Number of fruits per plant was calculated by dividing total number of fruits in a plot with number of plants in a plot.

Fruit diameter: Diameter of fruits selected randomly in plots of treated and control replications were measured in centimeter.

Fruit weight: Five fruits randomly selected in each treatment were weighted. The fruit weight was calculated with total weight of five fruits divided by total number of fruits.

Fruit yield/plot: Total fruits yield of all the pickings for each plot was recorded in $\mathrm{kg}$.

Avoidable yield losses: Yield loss was calculated by the following formula.

Yield loss $(\%)=\frac{\text { Yield of protected plant }- \text { yield of unprotected plant }}{\text { Yield of protected plants }} \times 100$

Statistical analysis: Data obtained for each treatment were statistically analyzed following the procedure of Randomized Block Design. Calculation was made after applying the test of significance of means. The percentage data for disease incidence was transformed to Archsine [25].

$\operatorname{Sin}^{-1}=\sqrt{\text { Percent disease incidence before statistical analysis }}$

\section{Results}

\section{Disease initiation}

Experimental data presented in Table 1 have clearly indicated that all the extracts significantly delayed the appearance of disease symptoms 
Table 1. Effect of botanicals on disease initiation and disease incidence in watermelon plants.

\begin{tabular}{|c|c|c|c|}
\hline Treatments & $\begin{array}{c}\text { Disease } \\
\text { initiation (DAS) }\end{array}$ & $\begin{array}{c}\text { Disease } \\
\text { incidence }(\%)\end{array}$ & $\begin{array}{c}\text { Reduction } \\
\text { in disease } \\
\text { incidence }(\%)\end{array}$ \\
\hline $\begin{array}{c}\mathrm{T}_{1}=\text { Seed treatment with } \\
\text { Boerhaavia diffusa root extract } \\
\text { (BD) }\end{array}$ & 20.00 & 75.28 & 8.58 \\
\hline $\begin{array}{c}\mathrm{T}_{2}=\text { Seed treatment with } \\
\text { Clerodendrum aculeatum leaf } \\
\text { extract (CA) }\end{array}$ & 19.50 & 77.85 & 5.46 \\
\hline $\begin{array}{c}\mathrm{T}_{3}=\text { Seed treatment with } \\
\text { Azadirachta indica leaf extract } \\
\text { (AI) }\end{array}$ & 20.00 & 76.76 & 6.78 \\
\hline $\begin{array}{c}\mathrm{T}_{4}=\text { Seed treatment with Terminalia } \\
\text { arjuna } \text { bark extract (TA) }\end{array}$ & 19.00 & 78.58 & 4.57 \\
\hline $\mathrm{T}_{5}=$ Foliar sprays of $\mathrm{BD}$ & 48.75 & 50.06 & 39.23 \\
\hline $\mathrm{T}_{6}=$ Foliar sprays of CA & 36.00 & 59.88 & 27.28 \\
\hline $\mathrm{T}_{7}=$ Foliar sprays of AI & 43.50 & 53.73 & 34.75 \\
\hline $\mathrm{T}_{8}=$ Foliar sprays of TA & 28.50 & 62.68 & 23.88 \\
\hline $\mathrm{T}_{9}=\mathrm{T}_{1}+\mathrm{T}_{5}$ & 66.50 & 37.68 & 54.24 \\
\hline $\mathrm{T}_{10}=\mathrm{T}_{2}+\mathrm{T}_{6}$ & 47.75 & 44.77 & 45.63 \\
\hline $\mathrm{T}_{11}=\mathrm{T}_{3}+\mathrm{T}_{7}$ & 58.00 & 39.46 & 52.08 \\
\hline $\mathrm{T}_{12}=\mathrm{T}_{4}+\mathrm{T}_{8}$ & 35.25 & 53.70 & 34.79 \\
\hline $\mathrm{T}_{13}=$ Control & 18.50 & 82.35 & 0.00 \\
\hline $\mathrm{T}_{14}=$ Foliar spray of insecticide & 70.50 & 35.35 & 57.07 \\
\hline $\mathrm{CD}$ at $5 \%$ & 1.988 & 3.045 & - \\
\hline $\mathrm{SEm} \pm$ & 0.683 & 1.047 & - \\
\hline
\end{tabular}

at all the doses. However, 6 foliar sprays along with seed treatment with $B$. diffusa root extract was found most effective treatment which delayed appearance of symptom till 66.50 days after sowing (DAS) followed by 6 foliar sprays along with seed treatment with $A$. indica $(58.00$ DAS), 6 foliar sprays of $B$. diffusa (48.75 DAS), 6 foliar sprays along with seed treatment with C. aculeatum (47.75 DAS), 6 foliar sprays of $A$. indica (43.50), 6 foliar sprays of C. aculeatum (36.00 DAS), 6 foliar sprays along with seed treatment with T. arjuna bark extract (35.25 DAS), 6 foliar sprays of T. arjuna (28.50 DAS) seed treatment with B. diffusa and A. indica (20.00 DAS), seed treatment with $C$. aculeatum (19.50 DAS) and seed treatment with T. arjuna (20.00 DAS) as compared to untreated plants (18.50 DAS), respectively. However, in the plants having insecticides treatment the disease(s) initiation recorded was 70.50 DAS.

\section{Disease incidence}

Results presented in Table 1 revealed a gradual decrease in disease incidence with corresponding increase in number of sprays with $B$. diffusa root extract, $C$. aculeatum leaf extract $A$. indica leaf extract and T. arjuna bark extract (TA). Minimum reduction in disease incidence (54.24) percentage was recorded in seed treatment followed by 6 foliar sprays with $B$. diffusa, followed by seed treatment and 6 foliar sprays of A. indica leaf extract $(52.08 \%) \mathrm{T}_{10}(45.63 \%), \mathrm{T}_{5}(39.23 \%), \mathrm{T}_{12}(34.79 \%)$, $\mathrm{T}_{7}(24.75 \%), \mathrm{T}_{6}(34.75 \%), \mathrm{T}_{8}(23.88 \%), \mathrm{T}_{1}(8.58 \%), \mathrm{T}_{3}(6.78 \%), \mathrm{T}_{4}$ (4.57\%) and $\mathrm{T}_{2}(5.46 \%)$ as compared to control. However, $57.07 \%$ reduction in disease was recorded plants treated with insecticide (Figure 1, 2 and 3).

\section{Disease symptoms}

Symptoms severity was reduced in watermelon plants, treated with extracts from these plants.

\section{Vine length (m)}

Significant increase in number of vine length was recorded with all the botanicals. Maximum increase in vine length $(3.93 \mathrm{~m})$ was recorded in $\mathrm{T}_{9}$ (seed treatment followed by 6 foliar sprays of $B$. diffusa root extract) which was at par with the treatment $\mathrm{T}_{11}(3.70 \mathrm{~m})$ and significantly superior over rest of the treatments. On the other hand, maximum increase in vine length (106.84\%) was observed in the treatment $\mathrm{T}_{9}$ (seed treatment followed by six foliar sprays with B. diffusa root extract) followed by $\mathrm{T}_{11}(97.43 \%), \mathrm{T}_{5}(85.26 \%), \mathrm{T}_{10}$ (67.89\%), $\mathrm{T}_{7}(653.26 \%), \mathrm{T}_{12}(29.47 \%), \mathrm{T}_{13}(13.15 \%), \mathrm{T}_{8}(12.105)$ and $\mathrm{T}_{4}$ (2.565). However, in insecticide treated plants 114.73 per cent increase in vine length was recorded (Table 2).

\section{Number of fruits plant ${ }^{-1}$}

It is evidenced from the results presented in Table 2 that the significant increase in number of fruits per plant was recorded with all the botanicals. Maximum number of fruits per plant (2.60) was recorded in $\mathrm{T}_{9}$ (seed treatment followed by six foliar sprays with $B$. diffusa root extract) which was at par with $\mathrm{T}_{11}$ (2.36) and significantly superior over rest of the treatments. On the other hand, maximum increase in number of fruits per plant (120.33\%) was observed in treatment $\mathrm{T}_{9}$ (seed treatment followed by 6 foliar sprays with B. diffusa root extract) followed by $\mathrm{T}_{11}(100.00 \%), \mathrm{T}_{10}(78.81 \%), \mathrm{T}_{5}(77.96 \%)$, $\mathrm{T}_{12}(61.01 \%), \mathrm{T}_{7}$ (56.77\%), $\mathrm{T}_{6}(48.30 \%), \mathrm{T}_{8}(23.72 \%), \mathrm{T}_{1}(19.49 \%)$, $\mathrm{T}_{3}(16.94 \%), \mathrm{T}_{2}(11.86 \%), \mathrm{T}_{4}(5.93 \%)$ as compared untreated plant. However, an increase in fruit per plant was also recorded in insecticide treated plant (130.05\%).

\section{Fruit diameter $(\mathrm{cm})$}

A gradual increase in fruit diameter was recorded in all the botanicals with increase in number of sprays. Maximum fruit diameter $\left(21.16 \mathrm{~cm}\right.$ ) was recorded in the treatment $\mathrm{T}_{9}$ (seed treatment followed by six foliar sprays with $B$. diffusa root extract) which was at par with $\mathrm{T}_{11}$ (seed treatment and six foliar spray with $A$. indica) and significantly superior rest of the treatments. On the other hand, maximum increase in fruit diameter $\left(94.01 \%\right.$ ) was recorded in treatment $\mathrm{T}_{9}$ (seed treatment followed by six foliar sprays with $B$. diffusa root extract) as compared to other treatments (Table 2).

\section{Fruit weight (kg)}

A gradual increase in fruit weight was recorded in all the botanicals with increase in number of sprays. Maximum fruit weight $(3.62 \mathrm{~kg} /$ plant) was recorded in treatment $\mathrm{T}_{9}$ (seed treatment and six foliar sprays with $B$. diffusa root extract) which was at par with $\mathrm{T}_{11}$ (seed treatment and 6 foliar sprays of $A$. indica), $\mathrm{T}_{5}$ (foliar sprays of $B$. diffusa) and significantly superior over rest of the treatments. On the other hand, maximum increase in fruit weight (214.78\%) was recorded in treatment $\mathrm{T}_{9}$ (seed treatment followed by six foliar sprays with $B$. diffusa root extract) as compared to the other treatments (Table 3).

\section{Fruit yield plot $^{-1}(\mathrm{~kg})$}

Result present in the Table 3 indicated that significant increase in fruit yield per plant was recorded in all the botanicals with increasing in number of sprays. Maximum fruit yield per plot $(78.39 \mathrm{~kg} / \mathrm{plot})$ was recorded in treatment $\mathrm{T}_{9}$ (seed treatment followed by six foliar sprays with $B$. diffusa root extract) which was significantly superior over rest of the treatments. On the other hand, maximum increase in fruit yield (160.43\%) was recorded in treatment $\mathrm{T}_{9}$ (seed treatment followed by six foliar sprays with $B$. diffusa root extract) as compared to the other treatments. However, in insecticide treated plant fruit yield per plant $65.25 \mathrm{~kg} /$ plot was recorded. 
Table 2. Effect of botanicals on vine length, No of fruits/plant and fruit diameter of watermelon.

\begin{tabular}{|c|c|c|c|c|c|c|}
\hline Treatments & Vine length (m) & $\begin{array}{l}\text { Increase in vine } \\
\text { length }(\%)\end{array}$ & No of fruits/plant & $\begin{array}{l}\text { Increase in Number } \\
\text { of fruits/plant }(\%)\end{array}$ & Fruit diameter $(\mathrm{cm})$ & $\begin{array}{l}\text { Increase in fruit } \\
\text { diameter }(\%)\end{array}$ \\
\hline $\begin{array}{c}\mathrm{T}_{1}=\text { Seed treatment with Boerhaavia } \\
\text { diffusa root extract }(\mathrm{BD})\end{array}$ & 2.22 & 16.84 & 1.41 & 19.49 & 11.85 & 16.7 \\
\hline $\begin{array}{c}\mathrm{T}_{2}=\text { Seed treatment with Clerodendrum } \\
\text { aculeatum leaf extract (CA) }\end{array}$ & 2.05 & 15.00 & 1.32 & 11.86 & 11.09 & 9.47 \\
\hline $\begin{array}{c}\mathrm{T}_{3}=\text { Seed treatment with Azadirachta } \\
\text { indica leaf extract }(\mathrm{AI})\end{array}$ & 2.15 & 13.15 & 1.38 & 16.94 & 11.58 & 14.31 \\
\hline $\begin{array}{c}\mathrm{T}_{4}=\text { Seed treatment with Terminalia } \\
\text { arjuna barkextract }(\mathrm{TA})\end{array}$ & 1.95 & 2.56 & 1.25 & 5.93 & 10.59 & 4.54 \\
\hline $\mathrm{T}_{5}=$ Foliar sprays of BD & 3.52 & 85.26 & 2.10 & 77.96 & 18.10 & 78.67 \\
\hline $\mathrm{T}_{6}=$ Foliar sprays of CA & 2.40 & 26.31 & 1.75 & 48.30 & 15.01 & 48.17 \\
\hline $\mathrm{T}_{7}=$ Foliar sprays of AI & 3.14 & 65.26 & 1.85 & 56.77 & 14.29 & 41.06 \\
\hline $\mathrm{T}_{8}=$ Foliar sprays of TA & 2.13 & 12.10 & 1.46 & 23.72 & 13.25 & 30.79 \\
\hline $\mathrm{T}_{9}=\mathrm{T}_{1}+\mathrm{T}_{5}$ & 3.93 & 106.84 & 2.60 & 120.33 & 21.16 & 99.01 \\
\hline $\mathrm{T}_{10}=\mathrm{T}_{2}+\mathrm{T}_{6}$ & 3.19 & 67.89 & 2.11 & 78.81 & 18.78 & 46.05 \\
\hline $\mathrm{T}_{11}=\mathrm{T}_{3}+\mathrm{T}_{7}$ & 3.70 & 94.73 & 2.36 & 100.00 & 20.05 & 97.92 \\
\hline $\mathrm{T}_{12}=\mathrm{T}_{4}+\mathrm{T}_{8}$ & 2.46 & 29.47 & 1.90 & 61.01 & 15.13 & 49.35 \\
\hline $\mathrm{T}_{13}=$ Control & 1.90 & 0.00 & 1.18 & 0.00 & 10.13 & 0.00 \\
\hline$T_{14}=$ Foliar spray of insecticide & 4.08 & 114.73 & 2.75 & 133.05 & 19.65 & 93.97 \\
\hline $\mathrm{CD}$ at $5 \%$ & 0.331 & - & 0.307 & - & 1.525 & - \\
\hline $\mathrm{SEM} \pm$ & 0.114 & - & 0.105 & - & 0.524 & - \\
\hline
\end{tabular}

Table 3. Effect of botanicals on fruit weight, fruit yield of watermelon fruits.

\begin{tabular}{|c|c|c|c|c|c|c|}
\hline Treatments & $\begin{array}{c}\text { Fruit weight (kg/ } \\
\text { plant) }\end{array}$ & $\begin{array}{l}\text { Increase in fruit } \\
\text { weight (\%) }\end{array}$ & Fruit yield (kg/plot) & $\begin{array}{c}\text { Increase in fruit yield } \\
(\%)\end{array}$ & $\begin{array}{l}\text { Avoidable yield loss } \\
\text { (kg/plot) }\end{array}$ & $\begin{array}{c}\text { Avoidable Yield loss } \\
\text { (\%) }\end{array}$ \\
\hline $\begin{array}{c}\mathrm{T}_{1}=\text { Seed treatment with Boerhaavia } \\
\text { diffusa root extract }(\mathrm{BD})\end{array}$ & 1.75 & 52.17 & 39.15 & 30.06 & 9.05 & 23.11 \\
\hline $\begin{array}{c}\mathrm{T}_{2}=\text { Seed treatment with Clerodendrum } \\
\text { aculeatum leaf extract }(\mathrm{CA})\end{array}$ & 1.45 & 26.08 & 34.70 & 15.28 & 4.6 & 13.25 \\
\hline $\begin{array}{c}\mathrm{T}_{3}=\text { Seed treatment with Azadirachta } \\
\text { indica leaf extract }(\mathrm{AI})\end{array}$ & 1.60 & 39.13 & 37.29 & 23.88 & 7.19 & 19.28 \\
\hline $\begin{array}{c}\mathrm{T}_{4}=\text { Seed treatment with Terminalia } \\
\text { arjuna barkextract }(\mathrm{TA})\end{array}$ & 1.33 & 15.65 & 32.65 & 8.47 & 2.55 & 7.81 \\
\hline $\mathrm{T}_{5}=$ Foliar sprays of BD & 3.00 & 160.86 & 68.34 & 127.0 & 38.24 & 55.95 \\
\hline $\mathrm{T}_{6}=$ Foliar sprays of CA & 2.65 & 130.43 & 54.00 & 79.40 & 23.90 & 49.25 \\
\hline $\mathrm{T}_{7}=$ Foliar sprays of $\mathrm{AI}$ & 2.81 & 144.34 & 62.27 & 106.87 & 32.17 & 51.66 \\
\hline $\mathrm{T}_{8}=$ Foliar sprays of TA & 2.00 & 73.91 & 45.85 & 52.32 & 15.75 & 34.35 \\
\hline $\mathrm{T}_{9}=\mathrm{T}_{1}+\mathrm{T}_{5}$ & 3.62 & 214.78 & 78.39 & 160.43 & 48.29 & 61.60 \\
\hline $\mathrm{T}_{10}=\mathrm{T}_{2}+\mathrm{T}_{6}$ & 2.89 & 151.30 & 62.82 & 108.70 & 32.72 & 52.08 \\
\hline $\mathrm{T}_{11}=\mathrm{T}_{3}+\mathrm{T}_{7}$ & 3.40 & 195.65 & 71.46 & 137.40 & 41.36 & 57.87 \\
\hline $\mathrm{T}_{12}=\mathrm{T}_{4}+\mathrm{T}_{8}$ & 2.39 & 107.82 & 50.45 & 67.60 & 20.35 & 40.33 \\
\hline $\mathrm{T}_{13}=$ Control & 1.15 & 0.00 & 30.10 & 0.00 & 10.00 & 0.00 \\
\hline $\mathrm{T}_{14}=$ Foliar spray of insecticide & 3.20 & 178.26 & 65.25 & 116.77 & 35.15 & 53.86 \\
\hline $\mathrm{CD}$ at $5 \%$ & 0.629 & - & 2.787 & - & - & - \\
\hline $\mathrm{SEM} \pm$ & 0.216 & - & 0.958 & - & - & - \\
\hline
\end{tabular}

\section{Avoidable yield loss (\%)}

Maximum avoidable yield loss $(61.60 \%)$ was recorded in $\mathrm{T}_{9}$ (seed treatment +6 foliar sprays with $B$. diffusa root extract) which was significantly higher over rest of the treatments. Minimum per cent avoidable yield losses was recorded in the treatment $\mathrm{T}_{13}$ (control) which was significantly lower over rest of the treatments. However, in insecticide treated plants, avoidable yield loss recorded was $53.86 \%$ (Table 3). Attempts were made earlier for the management of viral diseases in watermelon crop through insecticides to prevent the movement of insect vectors. But all insecticides caused environmental pollution, health hazards and phytotoxicity. Use of these insecticides cannot be eliminated but can be avoided by some preventive measures including antiviral agents of plant origin. These antiviral agents of plant origin are non-chemicals, non-hazardous, easily bio-degradable, ecofriendly and did not have a residual effect.

\section{Discussion}

The antiviral potential of the botanical biopesticides isolated from a few higher plants has been established through the extensive work conducted by various workers [16-19,24,26-37]. The virus inhibitory potential of phytoprotein was demonstrated by the ability of phytoprotein to prevent the formation of necrotic lesions in hypersensitive hosts and in delaying the development of disease specific symptom in systemic hosts. This type of induction of resistance in plants has been referred to as induced systemic resistance (ISR).

The antiviral properties of the plant extracts have been shown due to certain novel proteins present in the extracts $[29,38]$. These proteins can be applied in the form of aqueous extracts of the plant part as purified proteins, the latter being more effective [18,19,30,32,39]. The precise mechanism of protection offered by these phytoproteins 


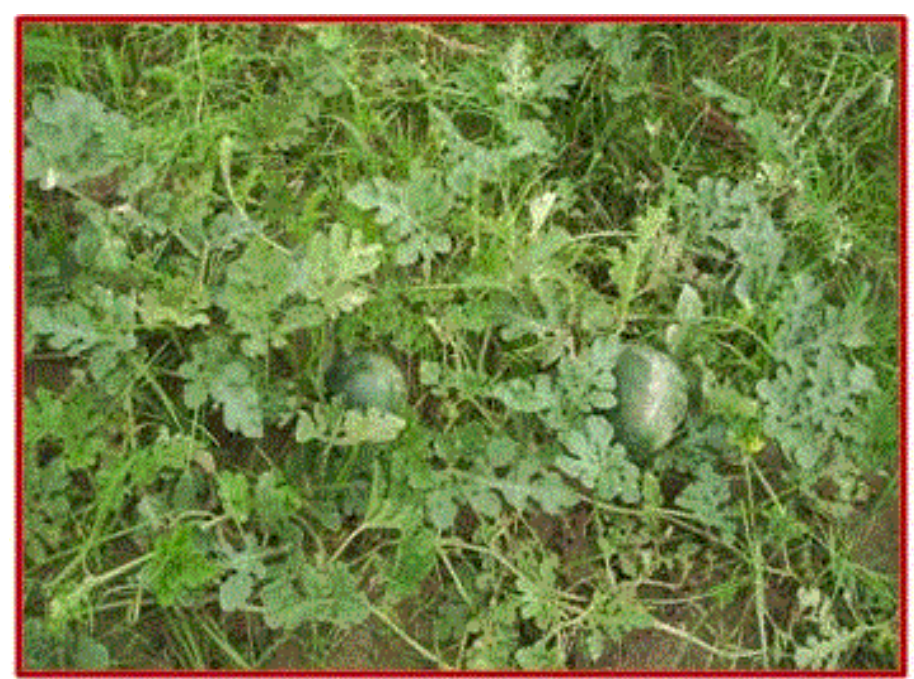

Seed treatment with $B$. diffsa root extract

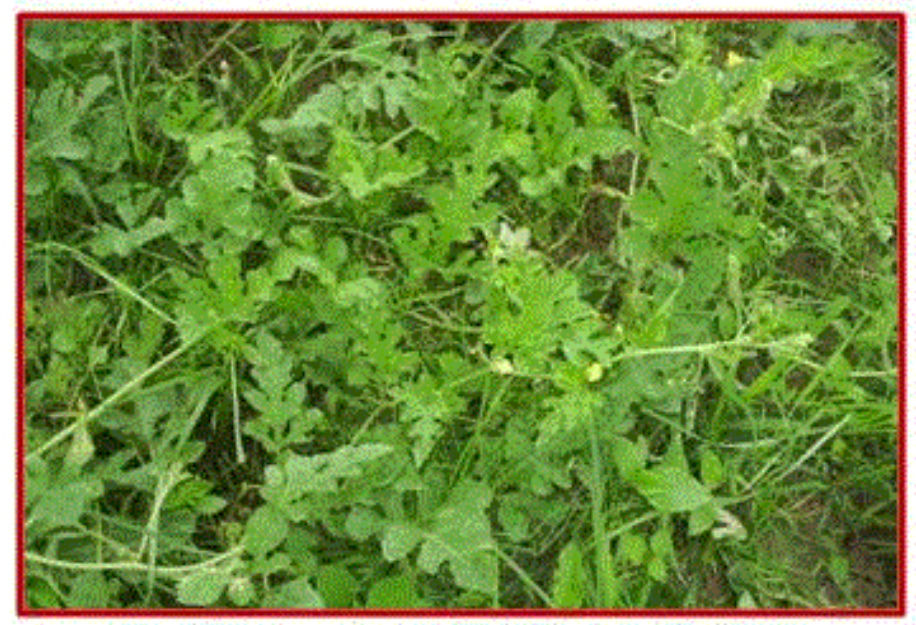

Seed treatment with $A$. indica leaf extract

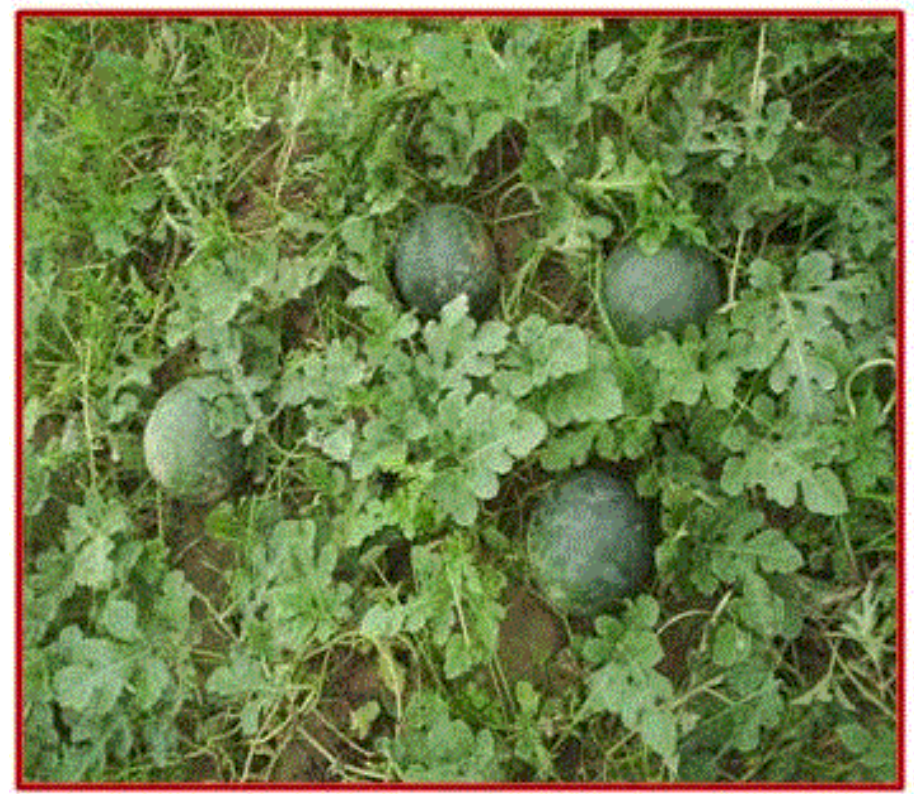

Foliar spays of $B$. diffesa root extract

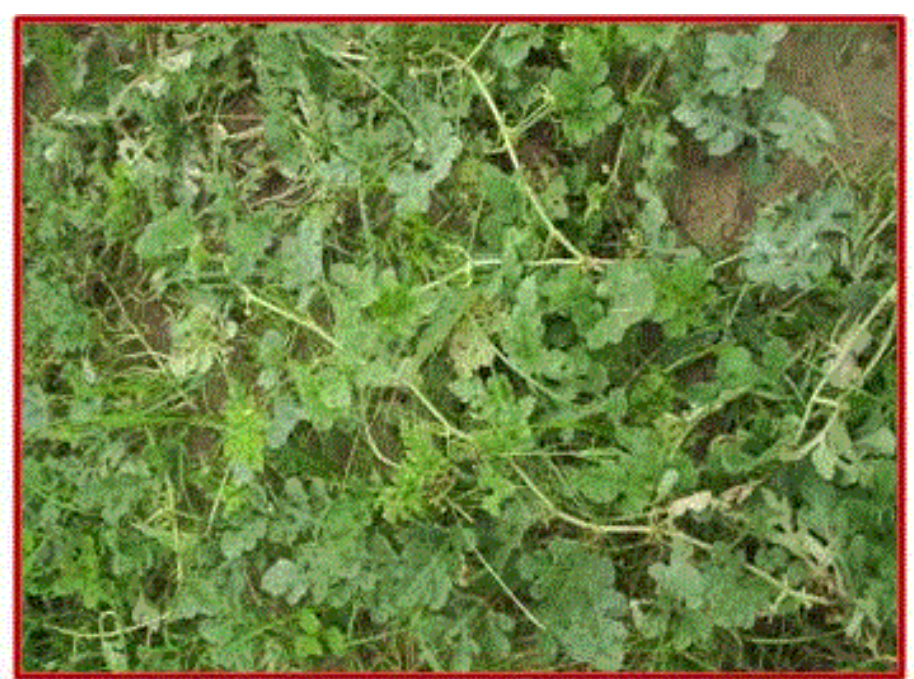

Seed trentment with $C$. acwlounon leaf extract

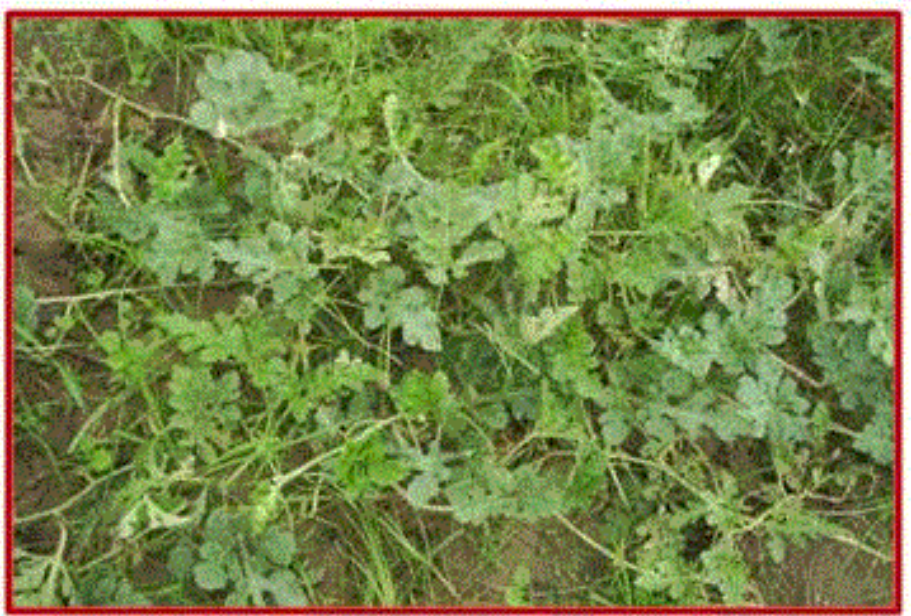

Seed treatment with $T$. ojina bank extract

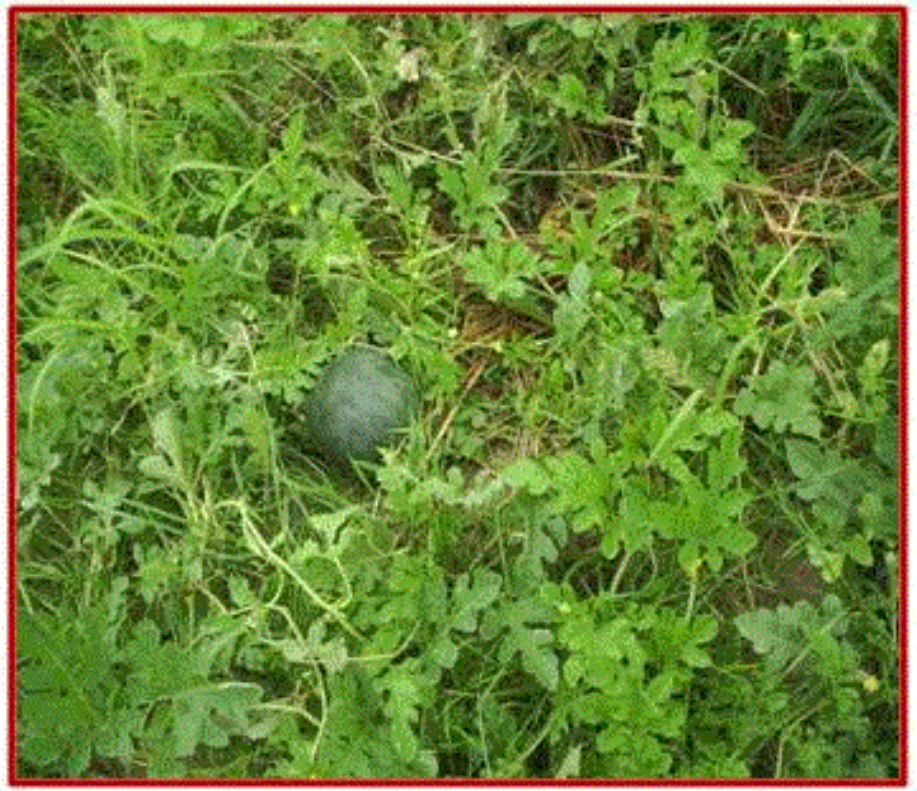

Foliar sprays of $C$. arvleanon leaf extract

Figure 1. Effect of botanical pesticides on mosaic disease of watermelon. 


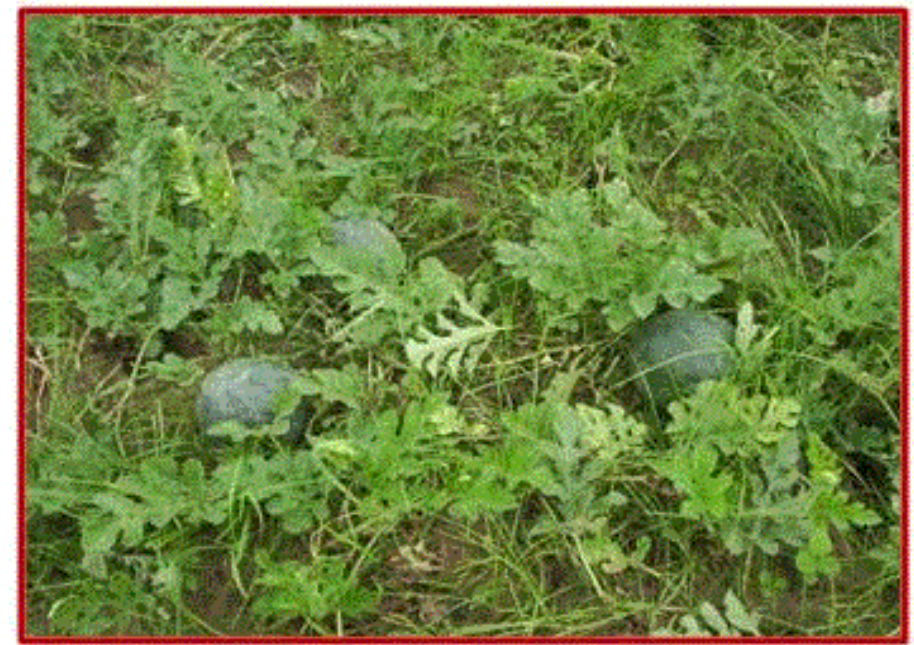

Foliar sprays of $A$. indica leaf extract

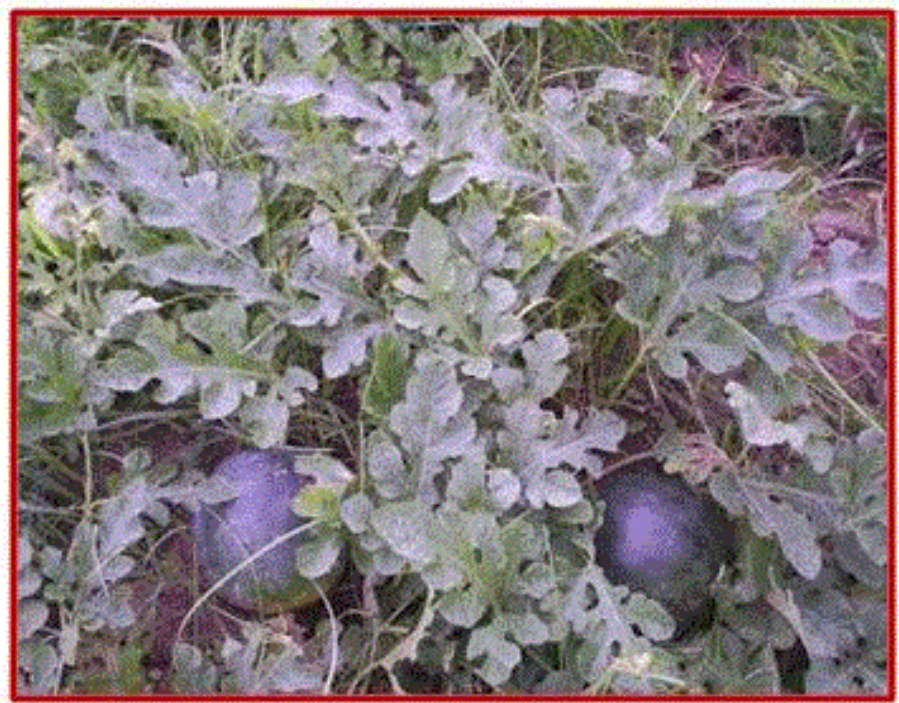

Seed treatment $+\operatorname{six}$ foliar sprays of $B$. differa root extract

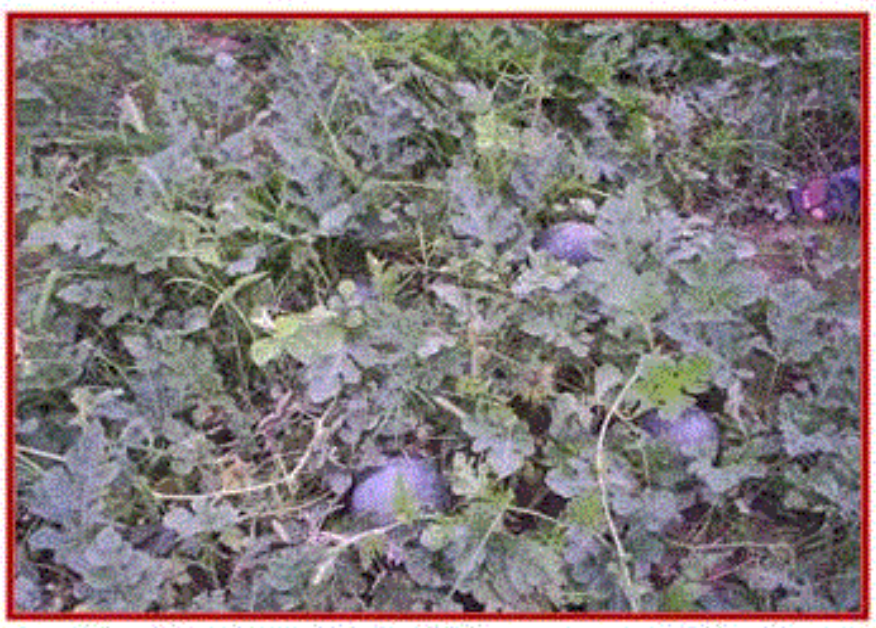

Seed treatment + six foliar spays of $A$. indica leaf extract

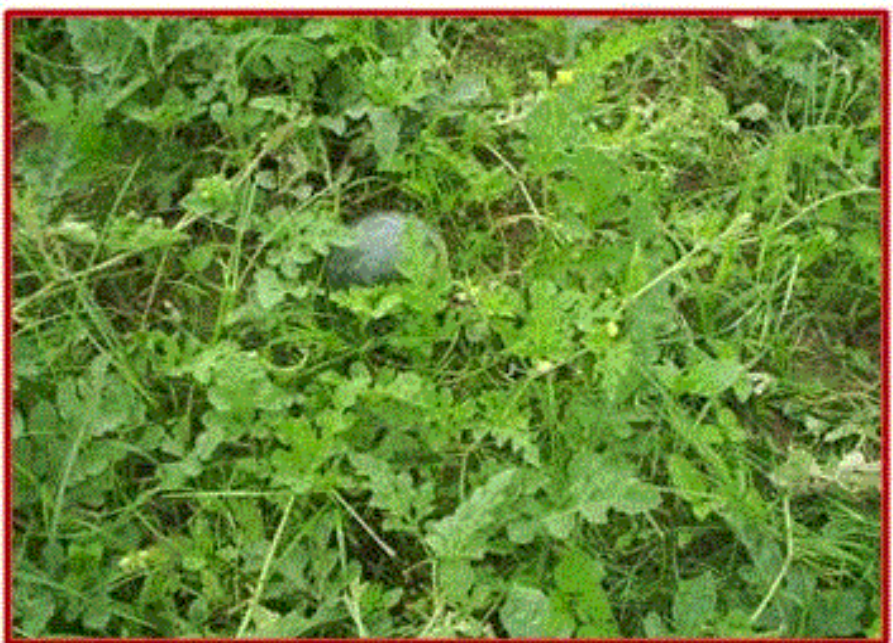

Foliar sprays of $T$ ajiona bark extract

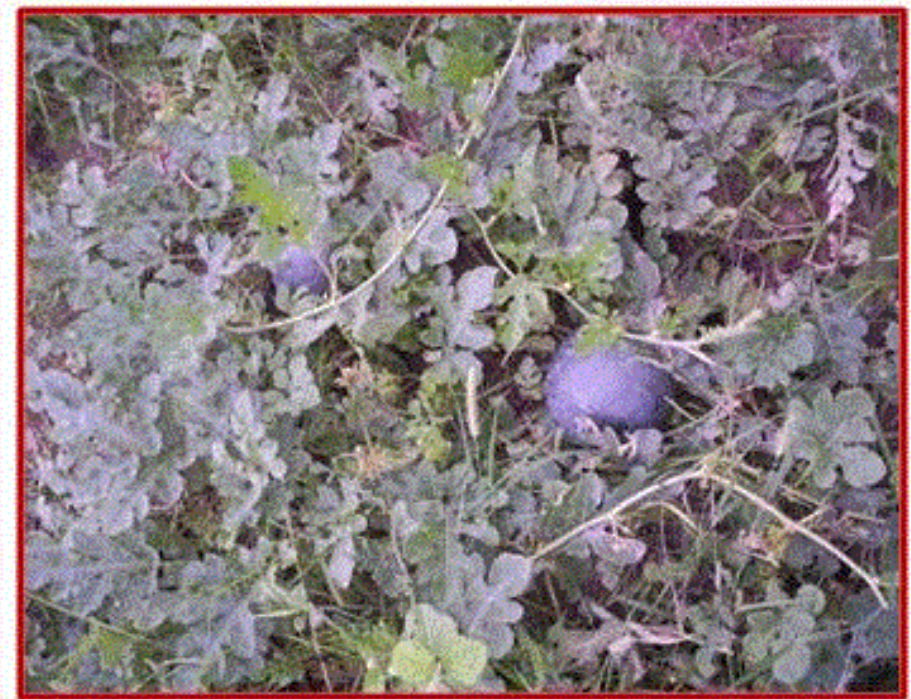

Seed treatment $+\operatorname{six}$ foliar sprays of $C$. arvleothos leaf extract

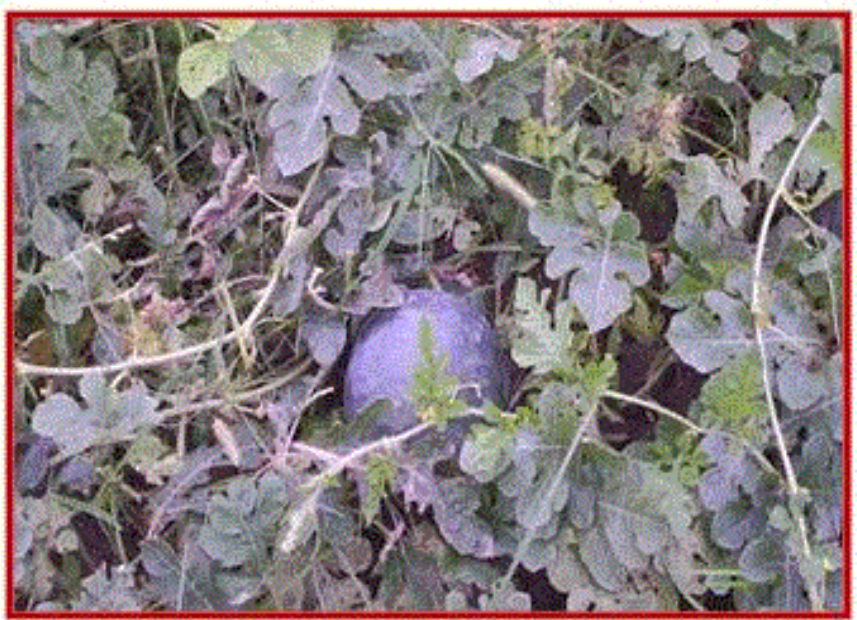

Seed treatment $+\operatorname{six}$ foliar spays of $T$. ojion bark extract

Figure 2. Effect of botanical pesticides on mosaic disease of watermelon. 


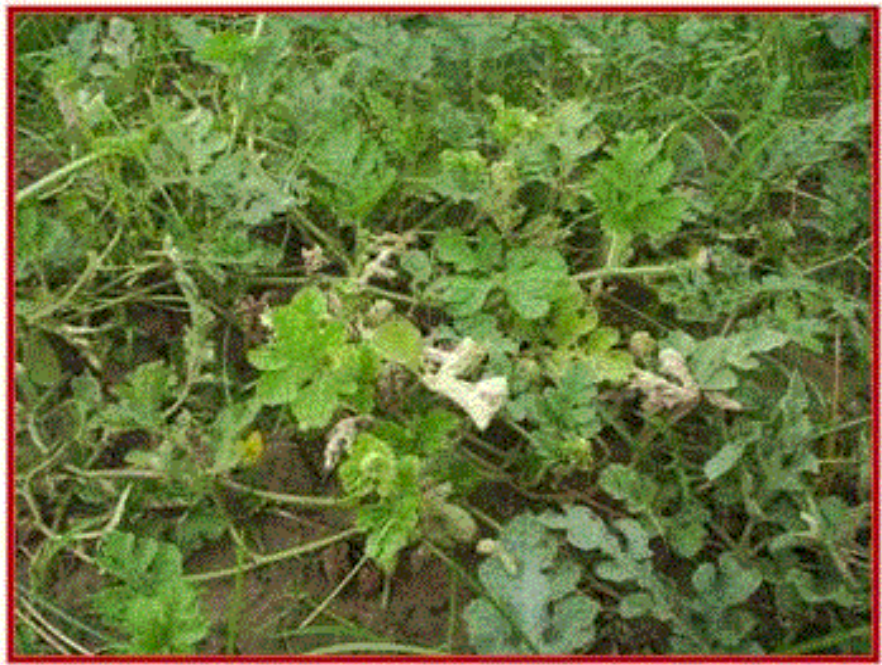

Control-1 (Water alone)

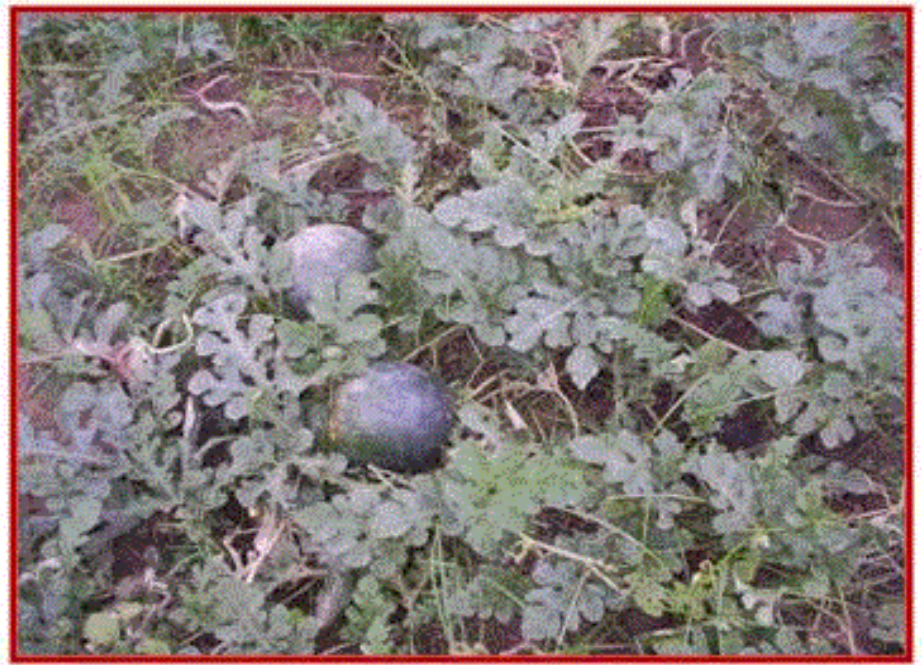

Control-2 (sprays with Endosolphan)

Figure 3. Effect of botanical pesticides on mosaic disease of watermelon.

has been worked out [26] and it has been shown that application of phytoproteins, induced formation of some virus inhibiting agent (VIA) in the treated plants. The VIA formation is sensitive to Actinomycin D, implying that VIA is a protein $[29,40]$.

An interesting virus disease preventing system that is based on a natural insect repellent rather than on a virus inhibitor has been developed by Awasthi and Rizvi [41]. Plant products were found to activate the defense system in susceptible plants. Spraying of extracts of non-host plants like B. diffusa, Clerodendrum aculeatum and a few others on susceptible plants like tobacco, tomato, and potato etc. induced systemic resistance in these plants towards subsequent virus infection. The development of macro molecules like polypeptides, glycoprotein or protein in the sprayed host has been responsible for acquiring the resistance $[29,30]$.

It is clear from the results that all the botanicals were effective in reducing disease incidence, symptom severity and their delayed appearance. The protective effect of these botanicals was more pronounced, if the number of sprays was increased from two to six. It was evident that plants which received six sprays were found to have highest reduction in disease incidence and gave highest biomass and yield. Similar results were obtained by Verma et al. [26] and Verma and Singh [42] on mungbean and urdbean through leaf extract of $B$. diffusa and C. aculeatum. Verma and Verma [43] also reported the management of some disease of mungbean and urdbean through leaf extract of $C$. aculeatum. The inhibitory effect of $B$. diffusa and C. aculeatum may be due to resistance inducers present in the plants induced systemic resistance against several viruses in hypersensitive as well as systemic hosts $[22,44,45]$. The inhibitory effect of $B$. diffusa root extract may be attributed in blocking of host cell receptors or to interference of virus synthesis in the host cell.

It has been demonstrated, that the glycoproteinaceous inhibitor present in B.diffusa when applied before virus inoculation induced synthesis of some translocable virus inhibitory or protective substances in the host plants [21]. The mechanism of virus inhibition by $B$. diffusa was studied and it was speculated that it alters the physiology of host cell in such a way that host cells no longer can support virus multiplication and ultimately the virus multiplication is affected to a great extent [23]. No other properties are required than that inhibitors differ from normal component of cells and because of this stimulate the cells to unusual activity. In present case also multiple sprays of $A$. indica on cucumber plants induced host cells to resist infection and reduced virus multiplication. Only very mild and delayed symptoms appeared on plants which received six sprays.

We have also observed in our findings that fortnightly sprayings of the extract from A. indica,B.diffusa, C. aculeatum and T arjuna reduced disease incidence and increased the yield. Thus, weekly / fortnightly sprays with partially purified concentrated preparation of antiviral agents, the disease incidence can be considerably lowered and yield of plants markedly improved $[9,30]$.These statements support our experimental findings. Furthermore, repeated and continuous use of these plant products is not associated with any health hazards and environmental pollution.

It is clear from the forgoing discussion that watermelon crop may be protected against infection and spread of a complex infection of gemini, cucumo and poty viruses by the multiple sprays of B.diffusa, A. indica, C. aculeatum and T. arjuna since cotyledon stage. Antiviral substance isolated from these plants, not only prevented viral infection but also enhanced the growth of plants, as we have observed better plant growth, significant increase in number of branches, flowering, fruiting and higher yields.

\section{References}

1. Halliwell RS, Johnson J, Cotner S (1979) Watermelon mosaic virus disease of squash, watermelon and pumpkin. Misc publn Texas Agri Experimental Station 1435: 5.

2. Greber RS (1969) Viruses infecting cucurbits in Queensland. Qd J Agric Anim Sci26:145-171.

3. Greber RS (1978) Watermelon mosaic virus-1 and 2 in Queensland cucurbit crops. AustJ Agric Res29:1235-1245.

4. Vani S (1987) Studies on viral diseases of muskmelon and watermelon. Ph. D Thesis, I.A.R.I, New Delhi.

5. Awasthi LP, Kumar P (2003a) Protection of some cucurbitaceous crops against natural infection of virus through Boerhaavia diffusa. Indian Phytopath56: 317.

6. Awasthi LP, and Kumar P (2003b) Prevention of infection and multiplication of cucumber green mottle mosaic virus in muskmelon treated with Boerhaavia diffusa Indian Phytopath56: 362. 
7. Kumar P, Awasthi LP (2003b) Prevention of Cucumber mosaic virus infection and spread in cucumber plants, treated with Boerhaavia diffusa inhibitor. Indian Phytopath56: 318 .

8. Kumar Pardeep, Awasthi L.P (2009) Prevention of Infection and Spread of Viral Diseases in Cucumber (Cucvmis Sativs L.) Through Botanicals. Journal of Plant Disease Sciences4: 25-32.

9. Kumar P, Awasthi LP, Sharma NK,Singh SP(2014) Performance of commercia cucumber cultivars against viral diseases under natural field conditions. International Journal of Plant Protection7: 238-239.

10. Strange EB, Guner N, Esbroeck ZPV, Wehner TC (2002) Screening the watermelon germplasms collection or resistance papaya ring spot virus Type-W. Crop Sci42: 13241330.

11. Jones P, Sattar MHA, Alkaff N (1988) Asp. Appl Biol17: 203.

12. Avgelis $\mathrm{AD}(1990)$ Melon necrotic spot virus in plastic houses on the island of Crete Acta Hortic287:349-354

13. Okuda M, Takeuchi S, Taba S, Kato K,Hanada K (2002) Melon yellow spot virus and watermelon silver mottle virus: outbreak of cucurbit infecting tospovirus in Japan. Acta Horticulturaep. 588.

14. Brown JK, Nelson MR(1989) Characterization of watermelon curly mottle virus, a geminivirus distinct from squash leaf curl virus. Ann Appl Biol115:243-252.

15. Awasthi LP, Chowdhury B, Verma HN (1984) Prevention of plant virus disease by Boerhaavia diffusa inhibitor. Int $J$ Trp Plant Disease 2: 41-44.

16. Awasthi LP, and Verma HN (2006) Boerhaavia diffuja - a wild herb with poten biological and antimicrobial properties. Asian-Agri History10: 55-68.

17. Awasthi LP, Kumar P, Singh S (2006) Incidence and symptomatology of cucumber mosaic virus in cucumber at farmers field of Faizabad district, U. P. Indian Phytopathology 59: 380

18. Awasthi LP, Singh Shyam, Sharma NK, Singh SK (2011) Induction of systemic resistance through antiviral agents of plant origin against papaya ring spot virus disease in papaya (Carica papaya L.). International Journal of Sustainable Agriculture 3: 54 57.

19. Singh SK, Awasthi LP, Singh S, Sharma NK (2011) Protection of mungbean and urdbean crops against vector borne mungbean yellow mosaic virus through botanicals. Curr Bot2: 08-11.

20. Verma HN, Awasthi LP (1979 a) Antiviral activity of Boerhaavia diffusa root extract and the physical properties of the virus inhibitor. Cand J Bot 57: 926-932.

21. Verma HN, Awasthi LP (1979 b) Prevention of virus infection and multiplication by leaf extract of Euphorbia hirta and the properties of the virus inhibitor. New Botanist6: $49-59$

22. Awasthi LP, and Singh, Pratap S (2015) Clerodendrum- A Novel Herb having Broad Spectrum Antimicrobial Properties. Asian Agri History 19: 33-44

23. Awasthi LP, Verma HN, Kluge S (2016) A possible mechanism of action for the Inhibition of plant viruses by an antiviral glycoprotein isolated from Boerhaavia diffusa roots. Jour Virology and Antiviral research 5: 1-8.

24. Singh S, Jangre N, Kumar S, Bisaria S, Awasthi LP (2016) Effect of artificial and natural infection of papaya ring spot virus on different papaya cultivars in Uttar Pradesh. Jour. Soil and Crops 26:203-212.

25. Fisher R, Yates F (1949) Statistical Tables for Biological, Agricultural and Medical Research, Oliver and Boyd, Edinburgh pp. 112.

26. Verma HN, Rastogi P, Prasad V, Srivastava S (1985) A possible control of natural virus infection of Vigna radiata and Vigna mungo by plant extracts. Indian J Plant Pthol3: $21-24$

27. Verma HN, Varsha, Baranwal VK (1995 a) Endogenous virus inhibitors from plants: Their physical and biological properties. In: Antiviral Proteins in Higher Plants, Chessin M, De Borde D, Zipf A (Eds) CRC Press, BocaRaton FI: 1-21.
28. Verma HN, Varsha, Baranwal VK (1995 b) Agricultural role in endogenous antiviral substance of plant origin. In: Antiviral Proteins in Higher Plants, Chessin M, De Borde D, Zipf A(Eds) CRC Press, BocaRaton, FI: 23-37.

29. Awasthi LP, Singh SP, Verma HN, Kluge S (2013) Further Studies on the Antivira Agent(s) Isolated from Host Plants, Pre-treated with Boerhaavia diffusa Glycoprotein. Virology and Mycology3: 124

30. Awasthi LP, Singh, Samir Pratap, Tripathi D (2014a) Eco-friendly Management of the Viral Diseases of Chilli (Capsicum annum L.). Research \& Review: Journal of Agriculture Science and Technology3: 11-16.

31. Chaubey AN, Awasthi LP, Singh SP (2014) Eco- Friendly management of viral diseases of potato. International Research Journal of Life Sciences2: 8-12.

32. Pandey AK, Awasthi LP, Pandey VP, Sharma NK, Kumar A, et al. (2014). Bioefficacy of root extract of Boerhaavia diffusa on yellow disease of ginger. American International Journal of Research in Formal, Applied and Natural Sciences5: 79-80.

33. Singh S,Awasthi LP (2002) Prevention of infection and spread of Bean common mosaic virus disease of mungbean and urdbean through botanicals. Indian J Plant Pathol 11: $63-65$.

34. Singh S, Awasthi LP (2004) Prevention of infection and spread of Mungbean yellow mosaic virus (MYMV) on urdbean (Vigna mungo) through Boerhaavia diffusa root extract. Indian J Pl Pathol22: 50-55.

35. Singh S, Awasthi LP, and Verma HN (2004) Prevention and control of yellow mosaic disease of mungbean by application of aqueous root extract of Boerhaavia diffusa. Indian Phytopath57: 303-304.

36. Singh S,Awasthi LP, Khan MN (2005) Management of yellow mosaic disease of mungbean and urdbean through aqueous root extract of Boerhaavia diffusa. New BatanistXXXII: 55-62.

37. Chaubey AN, Mishra RS, Awasthi LP (2017) Ecofriendly management of leaf curl disease of chilli through botanical biopesticides. Sci Fed Virology Research Journal1: $1-7$

38. Sharma NK, Awasthi LP (2017) Molecular characterization of antiviral Proteins, isolated from host Plants, pretreated with antiviral glycoprotein, isolated from roots of Boerhaavia diffusa plants.Journal of Human Virology and Retrovirology5: 1-5.

39. Singh AK, Najam A, Verma HN, Awasthi LP (2010) Control of Natural viral infection on Okra (Ablemoschus esculentus) by root extract of Boerhaavia diffusa. International Journal of Plant Protection 2: 195-198.

40. Verma HN, Awasthi LP (1980) Occurrence of a highly antiviral agent in plants treated with Boerhaavia diffusa inhibitor. Cand J Bot58: 2141-2144.

41. Awasthi LP, and Rizvi SMA (1999) Effect of Boerhaavia diffusa glycoprotein on the transmission of Tomato yellow leaf curl virus by Bemisia tabaci Gen. National Symposium on Vectors of Plant Diseases. Faizabad 2: 56.

42. Verma A, Singh RB (1994) Clerodendrum aculeatum a possible prophylactic agent against natural viral infection in mungbean. Ann Pl ProtecSc 2: 60-63.

43. Verma A, Verma HN (1993) Management of viral diseases of mungbean by Clerodendrum leaf extract. Indian J Pl Patholl1: 63-65.

44. Awasthi LP, Kluge, S, Verma HN (1987) Characteristic of an anitiviral agent in host plants. Indian J Viral 3: 156-169.

45. Verma HN, Srivastava S, Varsha, Kumar D (1996) Induction of systemic resistance in plants against viruses by a basic protein from Clerodendrum aculeatum leaves. Phytopathol86: 485-492.

46. He C, Zhang W, Hu X, Singh M, Xiong X, et al. (2014) Molecular characterization of a Chinese isolate of potato virus A (PVA) and evidence of a genome recombination event between PVA variants at the 3'-proximal end of the genome. Arch Virol 159. 2457-2462.[Crossref]

47. Jain RK, Pappu HR, Pappu SS, Akella Vani (1998) Watermelon bud necrosis tospovirus from India is a distinct virus species belonging to serogroup IV. Archives of Virology143:1637-44.

Copyright: (C2017 Sharma NK. This is an open-access article distributed under the terms of the Creative Commons Attribution License, which permits unrestricted use, distribution, and reproduction in any medium, provided the original author and source are credited. 